\title{
Crystal Engineering With the Uranyl Cation II. Mixed aliphatic carboxylate/aromatic pyridyl Coordination Polymers: Synthesis, Crystal Structures and Sensitized Luminescence.
}

\section{Supporting Information}

Including the following:

Supporting Fig. 1. Fluorescence spectra of $\left(\mathrm{UO}_{2}\right)_{2}\left(\mathrm{C}_{5} \mathrm{H}_{6} \mathrm{O}_{4}\right)_{3} \cdot\left(\mathrm{C}_{10} \mathrm{H}_{10} \mathrm{~N}_{2}\right)\left(\mathrm{H}_{2} \mathrm{O}\right)_{2}(5)$

Supporting Fig. 2. Fluorescence spectra of $\mathrm{UO}_{2}\left(\mathrm{C}_{6} \mathrm{H}_{8} \mathrm{O}_{4}\right)\left(\mathrm{C}_{10} \mathrm{H}_{8} \mathrm{~N}_{2}\right)(\mathbf{6})$

Supporting Fig. 3. Fluorescence spectra of $\left(\mathrm{UO}_{2}\right)_{2}\left(\mathrm{C}_{7} \mathrm{H}_{10} \mathrm{O}_{4}\right)_{2}\left(\mathrm{C}_{7} \mathrm{H}_{11} \mathrm{O}_{4}\right)_{2} \cdot\left(\mathrm{C}_{10} \mathrm{H}_{8} \mathrm{~N}_{2}\right)\left(\mathrm{C}_{10} \mathrm{H}_{10} \mathrm{~N}_{2}\right)$ $\left(\mathrm{H}_{2} \mathrm{O}\right)_{2}(7)$

Supporting Fig. 4. Fluorescence spectra of $\left(\mathrm{UO}_{2}\right)_{4}(\mathrm{O})_{2}\left(\mathrm{H}_{2} \mathrm{O}\right)_{2}\left(\mathrm{C}_{7} \mathrm{H}_{10} \mathrm{O}_{4}\right)_{2}\left(\mathrm{C}_{10} \mathrm{H}_{8} \mathrm{~N}_{2}\right) \cdot \mathrm{H}_{2} \mathrm{O}(\mathbf{8})$

Supporting Fig. 5. Fluorescence spectra of $\left(\mathrm{UO}_{2}\right)_{2}(\mathrm{O})\left(\mathrm{C}_{8} \mathrm{H}_{12} \mathrm{O}_{4}\right)\left(\mathrm{C}_{10} \mathrm{H}_{8} \mathrm{~N}_{2}\right)\left(\mathrm{H}_{2} \mathrm{O}\right)(9)$

Supporting Fig. 6. Fluorescence spectra of $\left(\mathrm{UO}_{2}\right)_{4}(\mathrm{O})_{2}\left(\mathrm{C}_{9} \mathrm{H}_{14} \mathrm{O}_{4}\right)_{2}\left(\mathrm{C}_{10} \mathrm{H}_{8} \mathrm{~N}_{2}\right)\left(\mathrm{H}_{2} \mathrm{O}\right)_{2}(\mathbf{1 0})$

Supporting Fig. 7. Fluorescence spectra of $\left(\mathrm{UO}_{2}\right)_{2}\left(\mathrm{C}_{10} \mathrm{H}_{16} \mathrm{O}_{4}\right)_{2}\left(\mathrm{C}_{10} \mathrm{H}_{8} \mathrm{~N}_{2}\right)(\mathbf{1 1})$

Supporting Fig. 8. Fluorescence spectra of $\left(\mathrm{UO}_{2}\right)_{2}\left(\mathrm{C}_{7} \mathrm{H}_{10} \mathrm{O}_{4}\right)_{3} \cdot\left(\mathrm{C}_{12} \mathrm{H}_{14} \mathrm{~N}_{2}\right)(\mathbf{1 3})$

Supporting Fig. 9. Fluorescence spectra of $\left(\mathrm{UO}_{2}\right)_{2}\left(\mathrm{C}_{9} \mathrm{H}_{14} \mathrm{O}_{4}\right)_{2}\left(\mathrm{C}_{12} \mathrm{H}_{12} \mathrm{~N}_{2}\right)(\mathbf{1 5})$ 


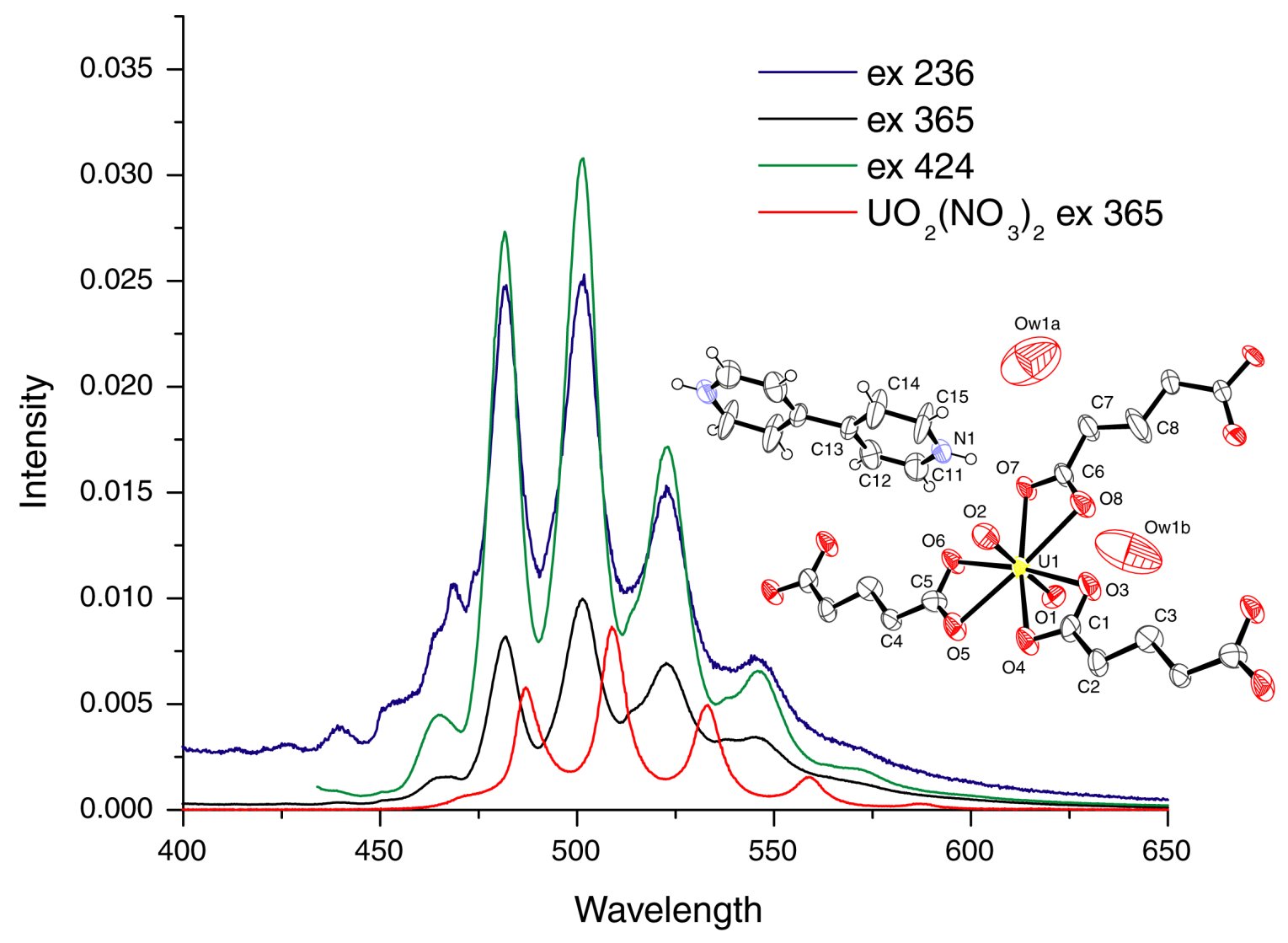

Supporting Fig. 1. Fluorescence spectra of $\mathrm{UO}_{2}\left(\mathrm{C}_{5} \mathrm{H}_{6} \mathrm{O}_{4}\right)_{3} \cdot\left(\mathrm{C}_{10} \mathrm{H}_{10} \mathrm{~N}_{2}\right)\left(\mathrm{H}_{2} \mathrm{O}\right)_{2}$ (5) illustrating the red shift when compared to $\mathrm{UO}_{2}\left(\mathrm{NO}_{3}\right)_{2} \cdot 6 \mathrm{H}_{2} \mathrm{O}$. The red line is the spectrum of $\mathrm{UO}_{2}\left(\mathrm{NO}_{3}\right)_{2} \cdot 6 \mathrm{H}_{2} \mathrm{O}$ excited at $365 \mathrm{~nm}$ while the blue, black and green lines are the spectra of $\mathrm{UO}_{2}\left(\mathrm{C}_{5} \mathrm{H}_{6} \mathrm{O}_{4}\right)_{3} \cdot\left(\mathrm{C}_{10} \mathrm{H}_{10} \mathrm{~N}_{2}\right)\left(\mathrm{H}_{2} \mathrm{O}\right)_{2}$ excited at 236,365 and $424 \mathrm{~nm}$ respectively. 


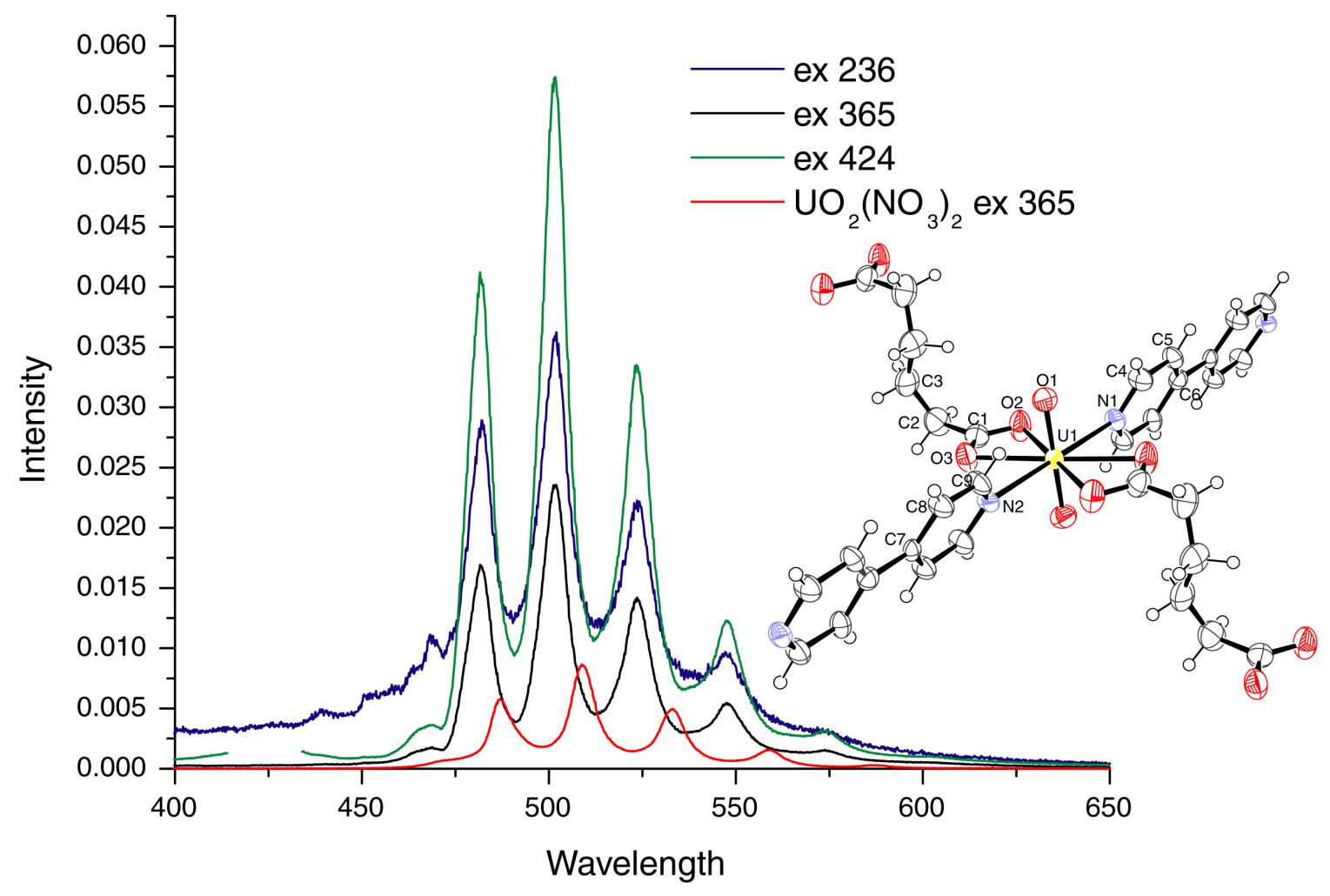

Supporting Fig. 2. Fluorescence spectra of $\mathrm{UO}_{2}\left(\mathrm{C}_{6} \mathrm{H}_{8} \mathrm{O}_{4}\right)\left(\mathrm{C}_{10} \mathrm{H}_{8} \mathrm{~N}_{2}\right)$ (6) illustrating the red shift when compared to $\mathrm{UO}_{2}\left(\mathrm{NO}_{3}\right)_{2} \cdot 6 \mathrm{H}_{2} \mathrm{O}$. The red line is the spectrum of $\mathrm{UO}_{2}\left(\mathrm{NO}_{3}\right)_{2} \cdot 6 \mathrm{H}_{2} \mathrm{O}$ excited at $365 \mathrm{~nm}$ while the blue, black and green lines are the spectra of $\mathrm{UO}_{2}\left(\mathrm{C}_{6} \mathrm{H}_{8} \mathrm{O}_{4}\right)\left(\mathrm{C}_{10} \mathrm{H}_{8} \mathrm{~N}_{2}\right)$ excited at 236, 365 and $424 \mathrm{~nm}$ respectively. 


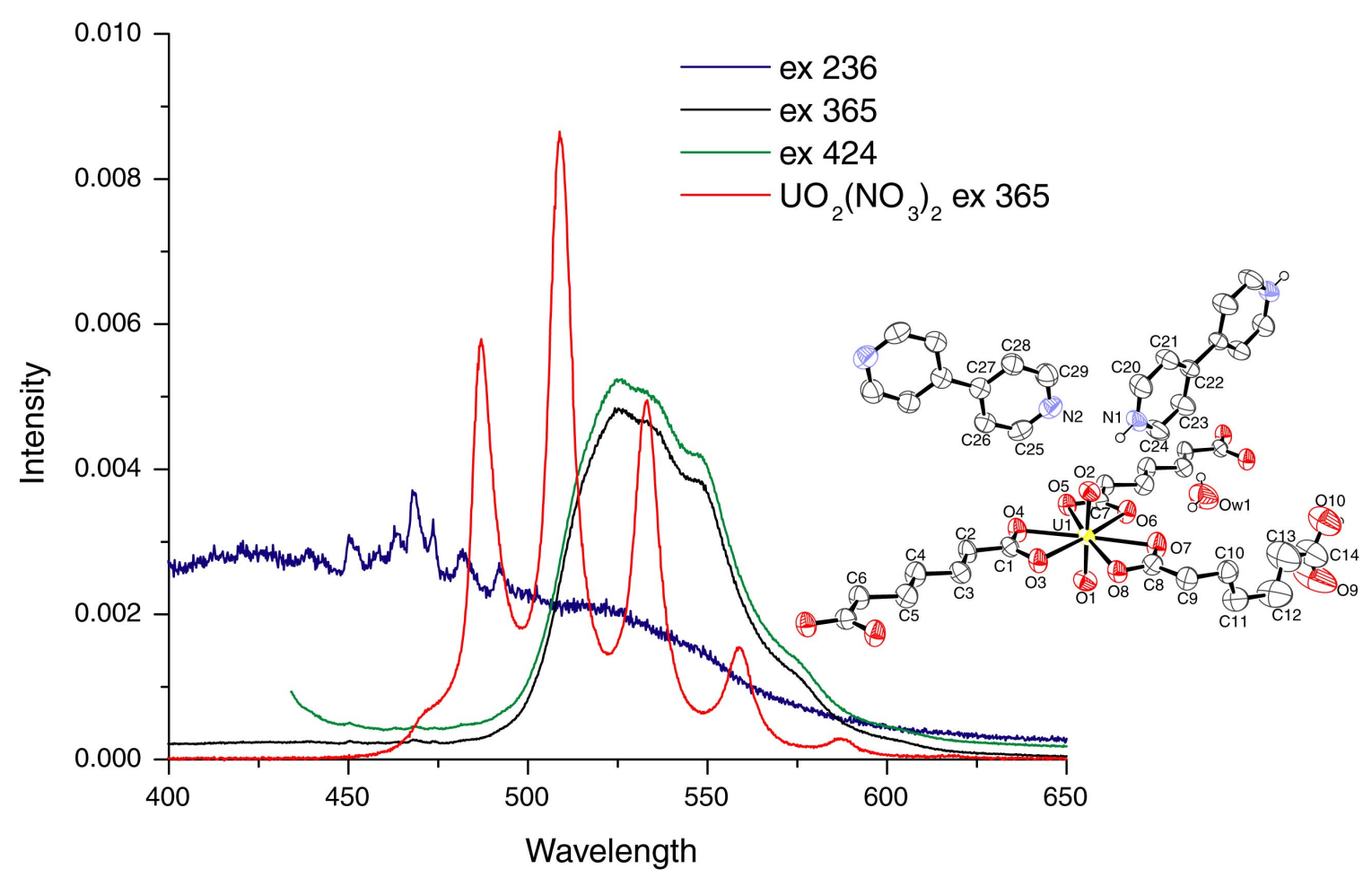

Supporting Fig. 3. Fluorescence spectra of $\left(\mathrm{UO}_{2}\right)_{2}\left(\mathrm{C}_{7} \mathrm{H}_{10} \mathrm{O}_{4}\right)_{2}\left(\mathrm{C}_{7} \mathrm{H}_{11} \mathrm{O}_{4}\right)_{2} \cdot\left(\mathrm{C}_{10} \mathrm{H}_{8} \mathrm{~N}_{2}\right)\left(\mathrm{C}_{10} \mathrm{H}_{10} \mathrm{~N}_{2}\right)$ $\left(\mathrm{H}_{2} \mathrm{O}\right)_{2}$ (7) illustrating the red shift when compared to $\mathrm{UO}_{2}\left(\mathrm{NO}_{3}\right)_{2} \cdot 6 \mathrm{H}_{2} \mathrm{O}$. The red line is the spectrum of $\mathrm{UO}_{2}\left(\mathrm{NO}_{3}\right)_{2} \cdot 6 \mathrm{H}_{2} \mathrm{O}$ excited at $365 \mathrm{~nm}$ while the blue, black and green lines are the spectra of $\left(\mathrm{UO}_{2}\right)_{2}\left(\mathrm{C}_{7} \mathrm{H}_{10} \mathrm{O}_{4}\right)_{2}\left(\mathrm{C}_{7} \mathrm{H}_{11} \mathrm{O}_{4}\right)_{2} \cdot\left(\mathrm{C}_{10} \mathrm{H}_{8} \mathrm{~N}_{2}\right)\left(\mathrm{C}_{10} \mathrm{H}_{10} \mathrm{~N}_{2}\right)\left(\mathrm{H}_{2} \mathrm{O}\right)_{2}$ excited at 236, 365 and $424 \mathrm{~nm}$ respectively. 


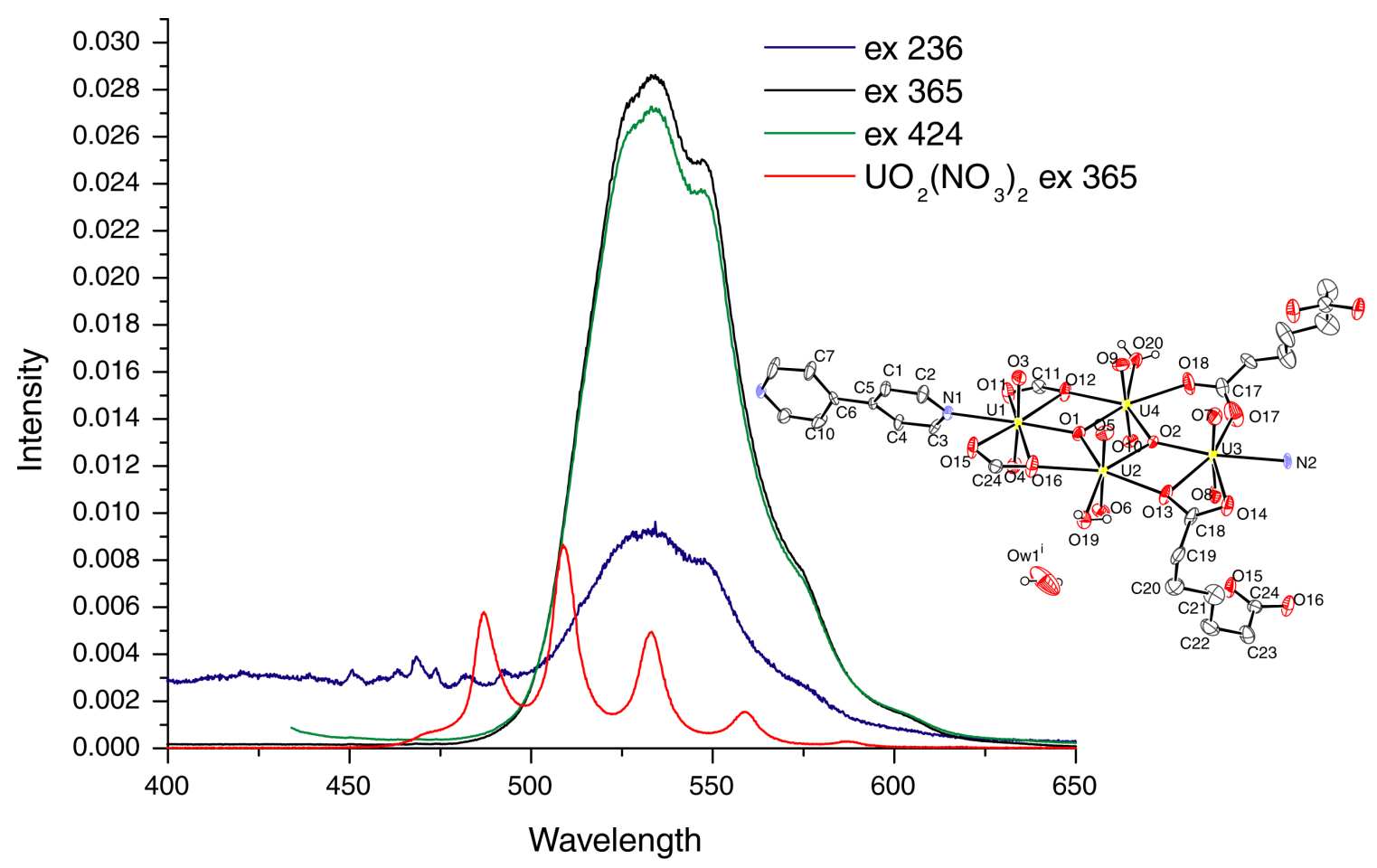

Supporting Fig. 4. Fluorescence spectra of $\left(\mathrm{UO}_{2}\right)_{4}(\mathrm{O})_{2}\left(\mathrm{H}_{2} \mathrm{O}\right)_{2}\left(\mathrm{C}_{7} \mathrm{H}_{10} \mathrm{O}_{4}\right)_{2}\left(\mathrm{C}_{10} \mathrm{H}_{8} \mathrm{~N}_{2}\right) \cdot \mathrm{H}_{2} \mathrm{O}$ (8) illustrating the red shift when compared to $\mathrm{UO}_{2}\left(\mathrm{NO}_{3}\right)_{2} \cdot 6 \mathrm{H}_{2} \mathrm{O}$. The red line is the spectrum of $\mathrm{UO}_{2}\left(\mathrm{NO}_{3}\right)_{2} \cdot 6 \mathrm{H}_{2} \mathrm{O}$ excited at $365 \mathrm{~nm}$ while the blue, black and green lines are the spectra of $\left(\mathrm{UO}_{2}\right)_{4}(\mathrm{O})_{2}\left(\mathrm{H}_{2} \mathrm{O}\right)_{2}\left(\mathrm{C}_{7} \mathrm{H}_{10} \mathrm{O}_{4}\right)_{2}\left(\mathrm{C}_{10} \mathrm{H}_{8} \mathrm{~N}_{2}\right) \cdot \mathrm{H}_{2} \mathrm{O}$ excited at 236,365 and $424 \mathrm{~nm}$ respectively. 


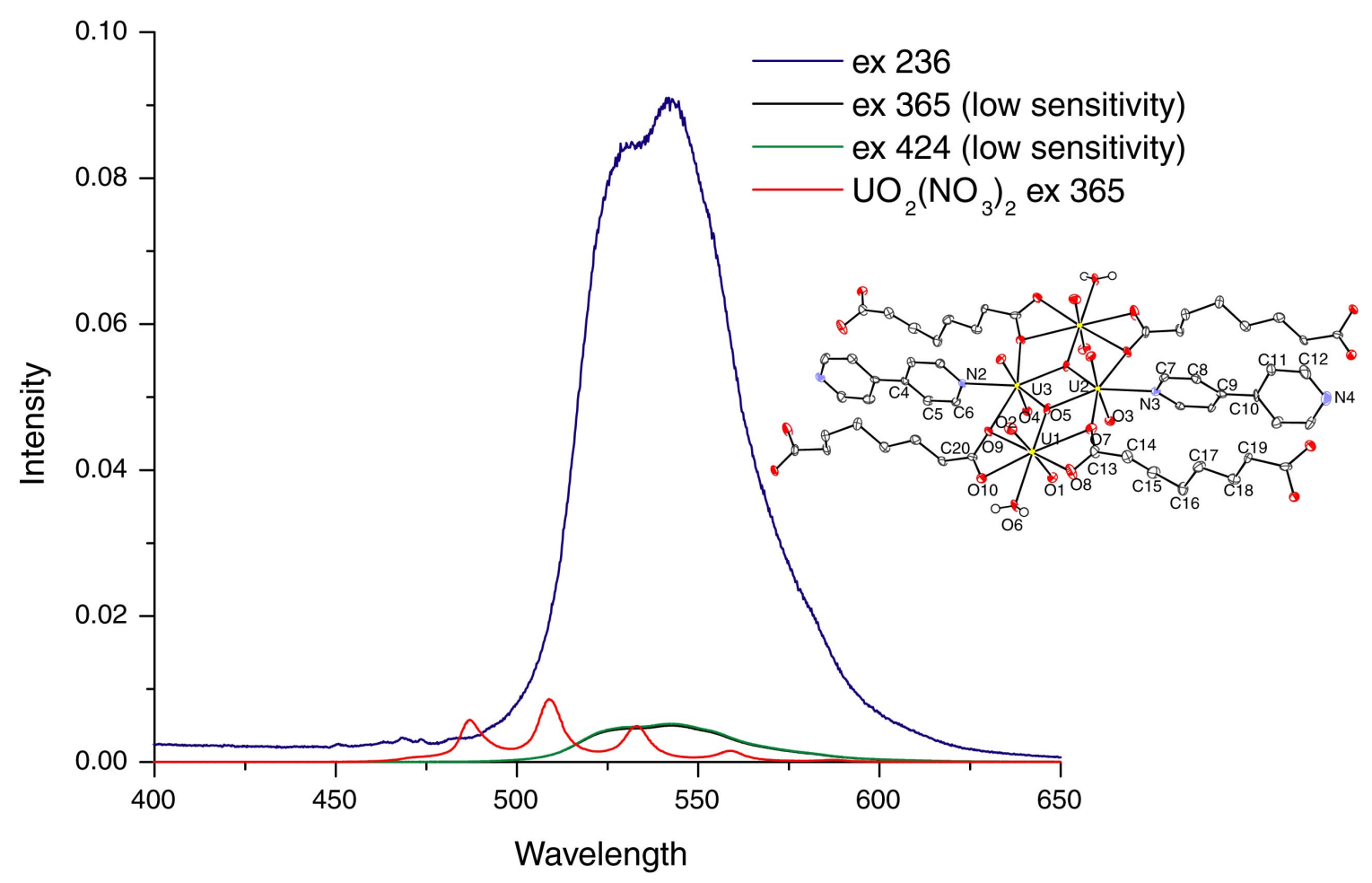

Supporting Fig. 5. Fluorescence spectra of $\left(\mathrm{UO}_{2}\right)_{2}(\mathrm{O})\left(\mathrm{C}_{8} \mathrm{H}_{12} \mathrm{O}_{4}\right)\left(\mathrm{C}_{10} \mathrm{H}_{8} \mathrm{~N}_{2}\right)\left(\mathrm{H}_{2} \mathrm{O}\right)$ (9) illustrating the red shift when compared to $\mathrm{UO}_{2}\left(\mathrm{NO}_{3}\right)_{2} \cdot 6 \mathrm{H}_{2} \mathrm{O}$. The red line is the spectrum of $\mathrm{UO}_{2}\left(\mathrm{NO}_{3}\right)_{2} \cdot 6 \mathrm{H}_{2} \mathrm{O}$ excited at $365 \mathrm{~nm}$ while the blue, black and green lines are the spectra of $\left(\mathrm{UO}_{2}\right)_{2}(\mathrm{O})\left(\mathrm{C}_{8} \mathrm{H}_{12} \mathrm{O}_{4}\right)\left(\mathrm{C}_{10} \mathrm{H}_{8} \mathrm{~N}_{2}\right)\left(\mathrm{H}_{2} \mathrm{O}\right)$ excited at 236,365 and $424 \mathrm{~nm}$ respectively. 


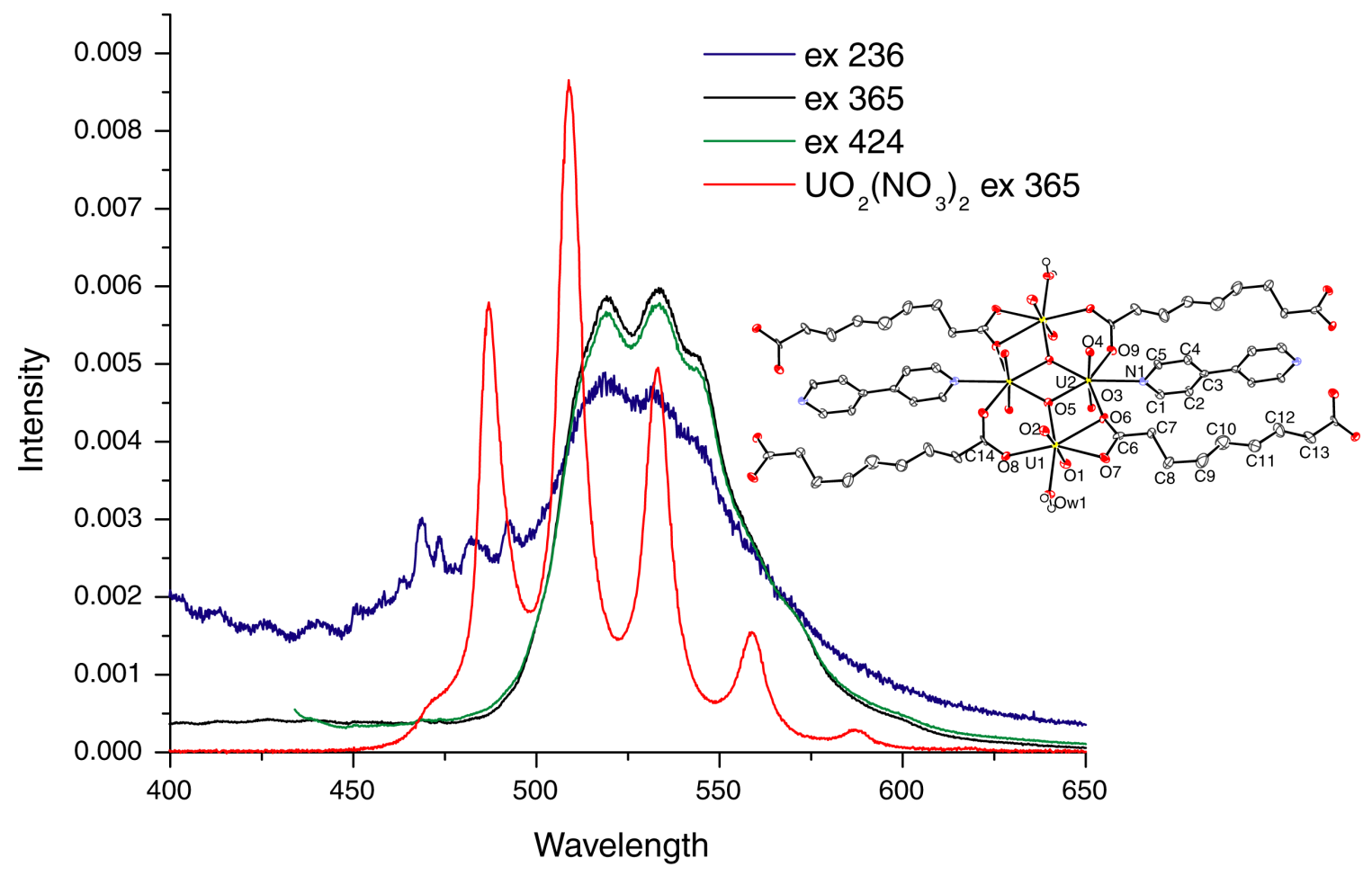

Supporting Fig. 6. Fluorescence spectra of $\left(\mathrm{UO}_{2}\right)_{4}(\mathrm{O})_{2}\left(\mathrm{C}_{9} \mathrm{H}_{14} \mathrm{O}_{4}\right)_{2}\left(\mathrm{C}_{10} \mathrm{H}_{8} \mathrm{~N}_{2}\right)\left(\mathrm{H}_{2} \mathrm{O}\right)_{2} \quad$ (10) illustrating the red shift when compared to $\mathrm{UO}_{2}\left(\mathrm{NO}_{3}\right)_{2} \cdot 6 \mathrm{H}_{2} \mathrm{O}$. The red line is the spectrum of $\mathrm{UO}_{2}\left(\mathrm{NO}_{3}\right)_{2} \cdot 6 \mathrm{H}_{2} \mathrm{O}$ excited at $365 \mathrm{~nm}$ while the blue, black and green lines are the spectra of $\left(\mathrm{UO}_{2}\right)_{4}(\mathrm{O})_{2}\left(\mathrm{C}_{9} \mathrm{H}_{14} \mathrm{O}_{4}\right)_{2}\left(\mathrm{C}_{10} \mathrm{H}_{8} \mathrm{~N}_{2}\right)\left(\mathrm{H}_{2} \mathrm{O}\right)_{2}$ excited at 236,365 and $424 \mathrm{~nm}$ respectively. 


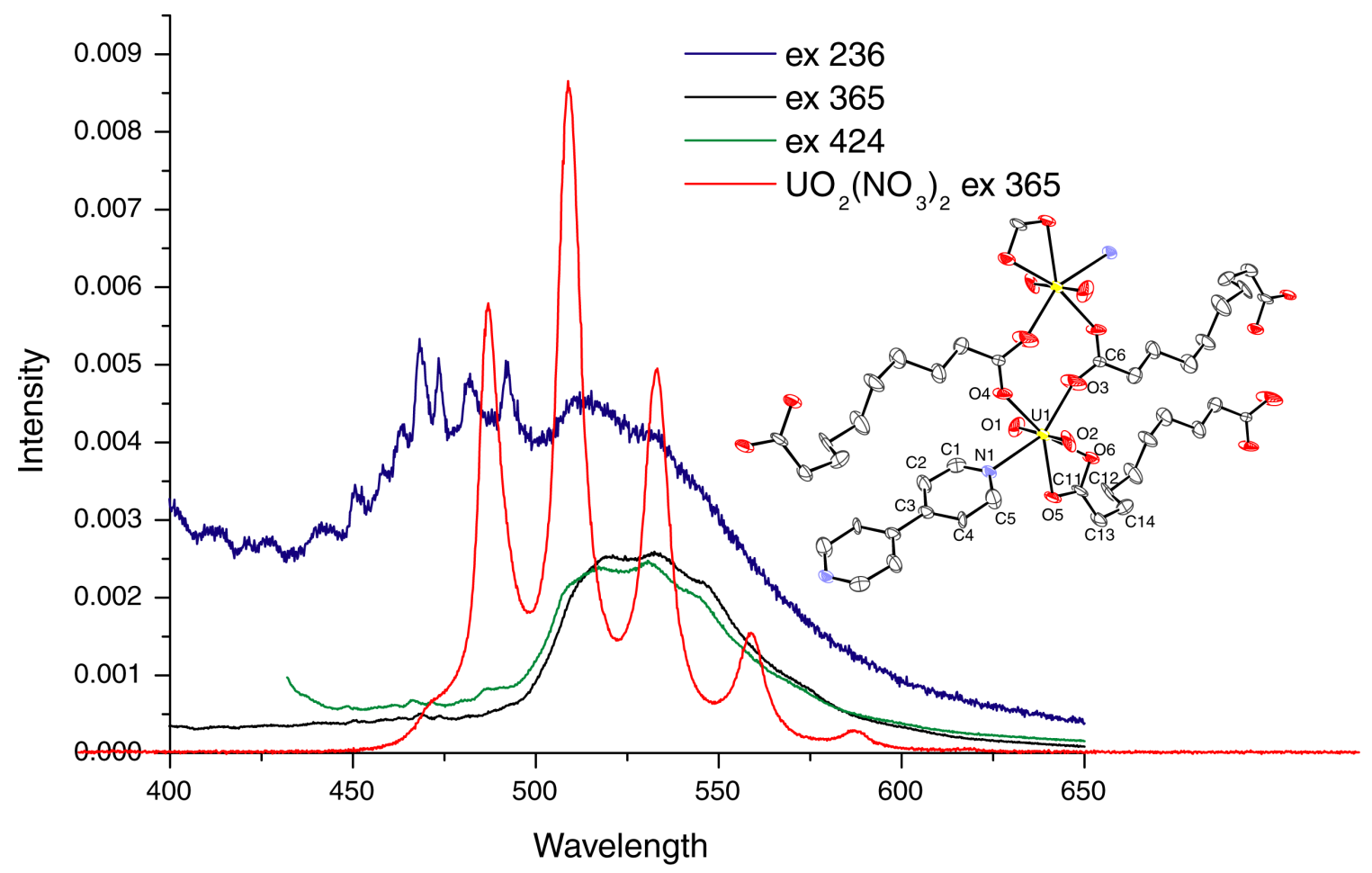

Supporting Fig. 7. Fluorescence spectra of $\left(\mathrm{UO}_{2}\right)_{2}\left(\mathrm{C}_{10} \mathrm{H}_{16} \mathrm{O}_{4}\right)_{2}\left(\mathrm{C}_{10} \mathrm{H}_{8} \mathrm{~N}_{2}\right)$ (11) illustrating the red shift when compared to $\mathrm{UO}_{2}\left(\mathrm{NO}_{3}\right)_{2} \cdot 6 \mathrm{H}_{2} \mathrm{O}$. The red line is the spectrum of $\mathrm{UO}_{2}\left(\mathrm{NO}_{3}\right)_{2} \cdot 6 \mathrm{H}_{2} \mathrm{O}$ excited at $365 \mathrm{~nm}$ while the blue, black and green lines are the spectra of $\left(\mathrm{UO}_{2}\right)_{2}\left(\mathrm{C}_{10} \mathrm{H}_{16} \mathrm{O}_{4}\right)_{2}\left(\mathrm{C}_{10} \mathrm{H}_{8} \mathrm{~N}_{2}\right)$ excited at 236,365 and $424 \mathrm{~nm}$ respectively. 


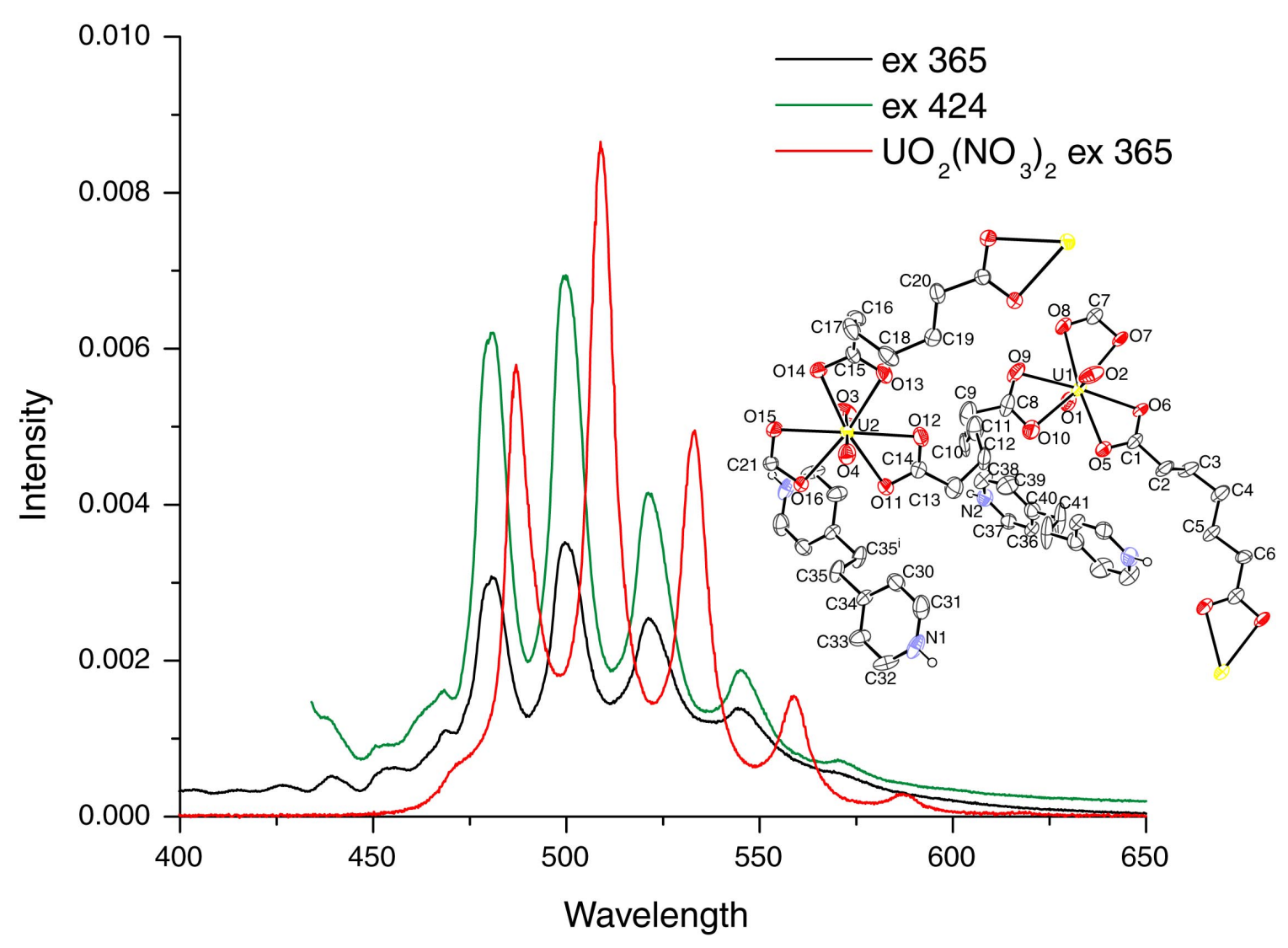

Supporting Fig. 8. Fluorescence spectra of $\left(\mathrm{UO}_{2}\right)_{2}\left(\mathrm{C}_{7} \mathrm{H}_{10} \mathrm{O}_{4}\right)_{3} \cdot\left(\mathrm{C}_{12} \mathrm{H}_{14} \mathrm{~N}_{2}\right)(\mathbf{1 3})$ illustrating the red shift when compared to $\mathrm{UO}_{2}\left(\mathrm{NO}_{3}\right)_{2} \cdot 6 \mathrm{H}_{2} \mathrm{O}$. The red line is the spectrum of $\mathrm{UO}_{2}\left(\mathrm{NO}_{3}\right)_{2} \cdot 6 \mathrm{H}_{2} \mathrm{O}$ excited at $365 \mathrm{~nm}$ while the black and green lines are the spectra of $\left(\mathrm{UO}_{2}\right)_{2}\left(\mathrm{C}_{7} \mathrm{H}_{10} \mathrm{O}_{4}\right)_{3} \cdot\left(\mathrm{C}_{12} \mathrm{H}_{14} \mathrm{~N}_{2}\right)$ excited at 365 and $424 \mathrm{~nm}$ respectively. 


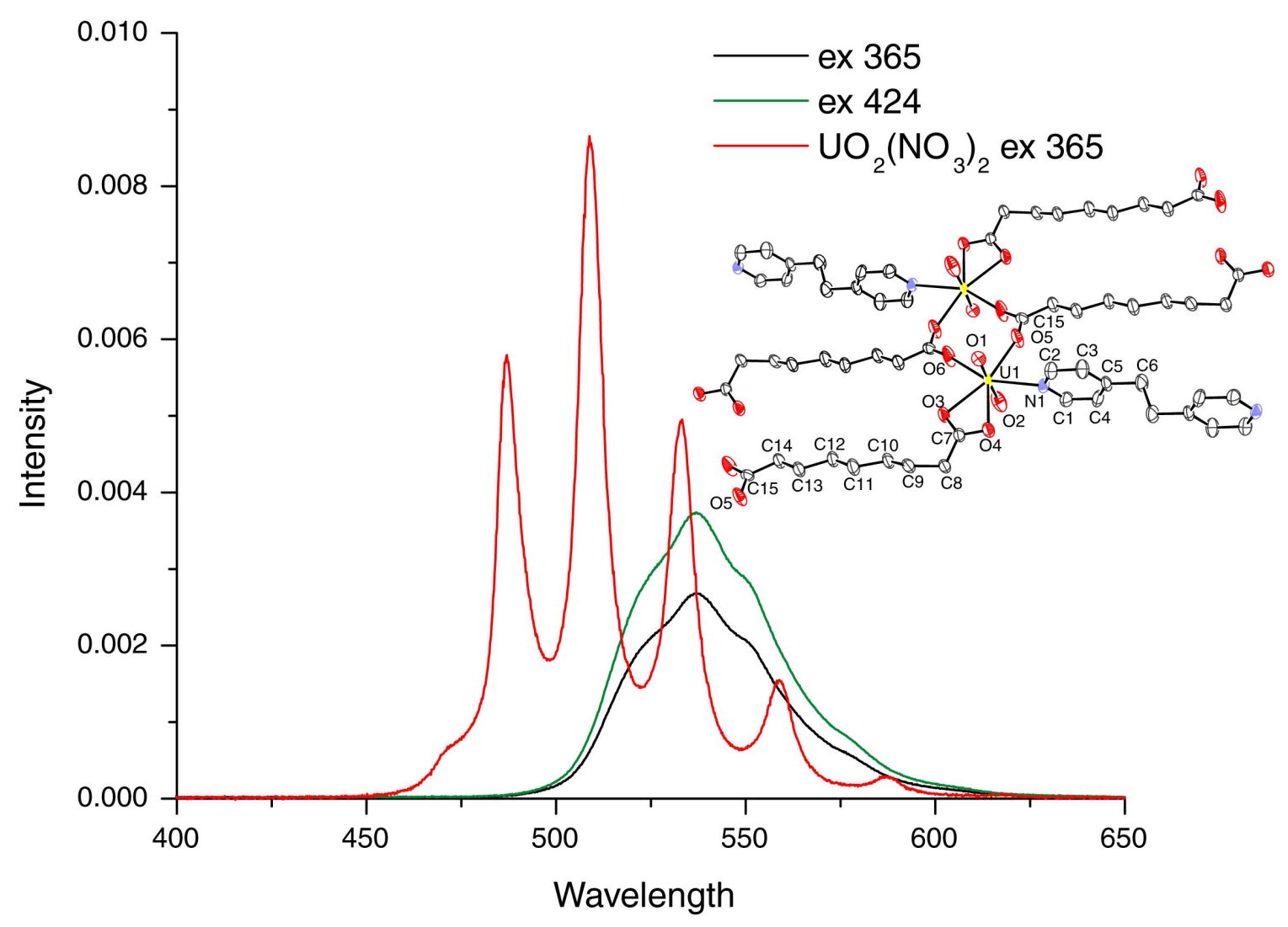

Supporting Fig. 9. Fluorescence spectra of $\left(\mathrm{UO}_{2}\right)_{2}\left(\mathrm{C}_{9} \mathrm{H}_{14} \mathrm{O}_{4}\right)_{2}\left(\mathrm{C}_{12} \mathrm{H}_{12} \mathrm{~N}_{2}\right)$ (15) illustrating the red shift when compared to $\mathrm{UO}_{2}\left(\mathrm{NO}_{3}\right)_{2} \cdot 6 \mathrm{H}_{2} \mathrm{O}$. The red line is the spectrum of $\mathrm{UO}_{2}\left(\mathrm{NO}_{3}\right)_{2} \cdot 6 \mathrm{H}_{2} \mathrm{O}$ excited at $365 \mathrm{~nm}$ while the black and green lines are the spectra of $\left(\mathrm{UO}_{2}\right)_{2}\left(\mathrm{C}_{9} \mathrm{H}_{14} \mathrm{O}_{4}\right)_{2}\left(\mathrm{C}_{12} \mathrm{H}_{12} \mathrm{~N}_{2}\right)$ excited at 365 and $424 \mathrm{~nm}$ respectively. 